\title{
Design of a Food Waste Management Method Case Study the Cafeteria in Mae Fah Luang University
}

\author{
P. Dokinagam and N. Laosipojana
}

\begin{abstract}
The residual food waste is one source of greenhouse gas, which results in climate change and directly increases the risk of water-, food-, vector- and rodent-borne diseases. This research aimed to develop an alternative approach for food waste management at Mae Fah Luang University (MFU). The appropriated way was evaluated based on the quantity of generated food waste together with the chemical and physical properties. The amount of food waste was collected from the canteens at MFU and then sampled to analysis. All information was evaluated to propose the proper food waste management method for MFU. The food waste generation at MFU, during academic year 2009-2013, was around $603.72 \mathrm{~kg} / \mathrm{day}$. The greenhouse gas emission from this food waste degradation was approximately 12678.015 $\mathrm{KgCO}_{2}$-eq/day and increasing every year. When using COWTEC $®$, this generated food waste could be converted to electricity around 10.8 MWh/year with $23104.5 \mathrm{~kg} / \mathrm{year}$ of fertilizer. Moreover, carbon emission is also reduced around 6058.80 $\mathrm{KgCO}_{2}$-eq/year. As the economic consideration, the payback period for this investment is around 4 years. Based on economic and environment health considerations, the appropriated way of food waste management at MFU is used as power generation.
\end{abstract}

Index Terms-Food waste, greenhouse gases, cost analysis, power generation.

\section{INTRODUCTION}

Food waste causes the environmental problem for both community and waste management system. Increasing of population is also resulted in higher amount of food waste. Nellemann, Programme [1] found that the world food production generated food scraps waste around $1 / 3$ or 1,300 million tons. This is the influence factor for generate greenhouse gases (GHG). Andersen, Boldrin [2] measured the GHG emission form organic house waste decomposition in Denmark. This data was used to compute the emission factor of methane and nitrogen dioxide which are $4.2 \mathrm{~kg}$ $\mathrm{CH}_{4} / \mathrm{Mg}$ wet waste (ww) and 0.30-0.55 $\mathrm{kg} \mathrm{N} \mathrm{N}_{2} \mathrm{O} / \mathrm{Mg}$.ww. These were equaled to $100-239 \mathrm{~kg} \quad \mathrm{CO}_{2}$-eq/Mg.ww. Meanwhile, Kim and Kim [3] studies the environmental effect from 4 different types of food waste deposal which are dry feeding, wet feeding, composting, and landfilling. By using the LCA technique, they found that GHG emission from dry feeding, wet feeding, composting, and landfilling

Manuscript received April 10, 2018; revised December 13, 2018. This work was supported in part by the Thailand Research Fund (TRF) and Office of the Higher Education (OHE) under Grant No. MRG5980139.

P. Dokmaingam is with the School of Health Science, Mae Fah Luang University, Chang Rai, Thailand (e-mail: pannipha.dok@mfu.ac.th).

N. Laosiripojana is with the Joint Graduate School of Energy and Environment, King Mongkut's University of Technology Thonburi, Bangkok, Thailand (e-mail: navadol@jgsee.kmutt.ac.th). produced are $200 \mathrm{~kg} \mathrm{CO}$-eq, $61 \mathrm{~kg} \mathrm{CO}_{2}$-eq, $123 \mathrm{~kg} \mathrm{CO}_{2}$-eq and $1010 \mathrm{~kg}$ of $\mathrm{CO}_{2}$-eq, respectively. Now a day, the desired solution for food waste management is energy production or related product instead of landfill or incineration [4]. As the work of [5] the current food waste-to-energy technology are divided into 3 categories: biological (such as anaerobic digestion, ethanol fermentation), thermal and thermochemical technologies (such as incineration, pyrolysis and gasification, hydrothermal carbonization). Based on environmental and energy-economic and health aspects, they suggest that the advantage of biological treatment process is simple and low investment cost. However, it has the essential limitation of a long treatment period and the possibility of bacteria inhibition when contact to contaminants in food waste.

In Thailand, MSW is mainly from residential, commercial, institutional and municipal services [6]. The institutional sector is one of the influence part that generated food waste. This the source of greenhouse gas, such as methane and carbon dioxide, from organic fermentation. There are many solutions that are developed to utilize the food waste in the university such as compost and biogas [7]. In this study, MFU was selected as the case study since this is small to medium scale of university in Thailand. Furthermore, the number of student is increased simultaneously. MFU is in the northern of Thailand. From statistic, the total of students were 17,249 in year 2009 and increased to 22,358 in 2013. When the number of population increasing, the problem food waste become significant. Then, this research aimed to evaluate the greenhouse gas emissions from food waste and calculate energy generation from food waste fermentation. Finally, the alternative ways for utilized food waste in MFU would be proposed.

\section{InTRODUCTION CHARACTERS OF FoOd WASTE IN MFU}

In MFU, the food waste is collected in 50 Liters plastic tank which is the mixture of liquid and solid organic waste. As the Thai food style, there are many herbs, such as galanga or lemon grass. These are the main components of solid part in the food waste. Then the collected food waste from all cafeterias is transferred outside the university twice a day. Therefore, the quantity of food waste was calculated from the density of mixture of waste in the plastic tank and total amounts of the tank in MFU. At the same time, the number of dishes and amount of students and staffs in MFU were also recorded during academic year 2014-2016. These data were then used for predict the quantity of food waste generation in MFU. 


\section{A. Review Stage Energy from Food Waste}

Now a day, there are many methods to utilize the food waste instead of sent to landfill or incineration. As work of Pham, Kaushik [5], the current technologies of food waste management include animal feed, anaerobic digestion. Furthermore, it can used as fertilizer [8]. In Thailand, the organic waste is mainly used for produce compost and energy [6]. Note that the food waste from MFU is normally used as animal feed. Moreover, the food waste is benefited for power generation.

One of the favored waste to energy technology from food waste is an anaerobic digestion technology. In this technology, food waste could be digested to generate electricity via anaerobic condition. It is a complicated biochemical process for digest organic waste to biogas. Biogas is a gas typically comprised of $60 \%$ methane $\left(\mathrm{CH}_{4}\right)$ and $40 \%$ carbon dioxide $\left(\mathrm{CO}_{2}\right)$. This can be used as fuel instead of natural gas. Mao, Feng [9] recommend that the nutrition is suitable for the growth of anaerobic microorganism. Furthermore, the residue from this process could be used as fertilizer. Moreover, biogas plants could reduce the methane emissions that cause greenhouse effects on the earth's atmosphere. However, impurities gases in biogas are corrosive to the metal parts of the utilized engines. Now a day, one of technology the suitable for small scale biogas generation from food waste as called $\mathrm{COWTEC}^{\circledR}$. It is a machines that generated biogas and compost via the Hi-solid Dry Continuous Fermentation Process. For this process, organic wastes are converted into useful by-products by microorganisms via "anaerobic digestion". In essence, the Hi-solid Dry Continuous Fermentation Process simply reduces nature's process of creating renewable energy \& organic fertilizer from many months to a matter of one day.

Anaerobic digestion of microorganisms in COWTEC@ are summarized in Fig. 1. Firstly, solid waste is hydrolyzed into a water-soluble. Then soluble organics is digested to organic acids. Then, this acids is converted to methane gas. At the meantime, the residue solid could be used as compost. The interested advantage of the $\mathrm{COWTEC}^{\circledR}$ is available for small scale organic waste. Its capacity is around $100 \mathrm{~kg} / \mathrm{day}$ of food waste that would be converted to biogas 1000 liters/day and generated compost around $150-250 \mathrm{~kg} /$ day.

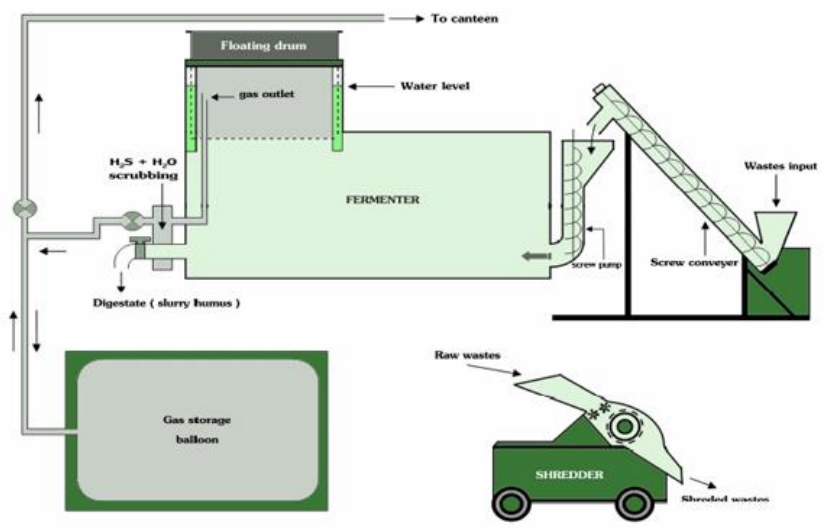

Fig. 1. Anaerobic digestion of COWTEC ${ }^{\circledR}$ machine [10].

\section{B. Economic Analysis}

Franchetti [11] evaluated the economic benefit of four different configurations of anaerobic digestion for food waste to energy conversion by using payback period analyses, Eq.1. This was also investigated in the work of the general economic assessment [12]. Net annual cash inflow

$$
\text { Payback }(\text { year })=\frac{\text { Cost of project }}{\text { Net annual cash inflow }} \text {. }
$$

\section{RESULTS AND DISCUSSION}

\section{A. Review Stage Energy from Food Waste}

TABLE I: THE GENERATED RESIDUAL FOOD WASTE IN MFU DURING

\begin{tabular}{|c|c|c|c|}
\hline Days & $\begin{array}{c}\text { No. of } \\
\text { people } \\
\text { (person) } \\
\text { Average } \\
\end{array}$ & $\begin{array}{l}\text { Food waste } \\
\text { (kg/30 days) }\end{array}$ & $\begin{array}{l}\text { Rate of waste } \\
\text { generation } \\
\text { (kg/person/day) }\end{array}$ \\
\hline 1 & 3293.33 & 1212.5 & 0.012 \\
\hline 2 & 3246.67 & 1212.5 & 0.012 \\
\hline 3 & 3768.33 & 1212.5 & 0.011 \\
\hline 4 & 3416.67 & 1212.5 & 0.012 \\
\hline 5 & 3238.33 & 2376.5 & 0.024 \\
\hline 6 & 3310 & 776 & 0.008 \\
\hline 7 & 3728.33 & 1212.5 & 0.011 \\
\hline 8 & 4016.67 & 776 & 0.006 \\
\hline 9 & 3706.67 & 1212.5 & 0.011 \\
\hline 10 & 3915 & 1212.5 & 0.010 \\
\hline 11 & 3185 & 1212.5 & 0.013 \\
\hline 12 & 2416.67 & 1212.5 & 0.017 \\
\hline 13 & 3065 & 1212.5 & 0.013 \\
\hline 14 & 3336.67 & 1746 & 0.017 \\
\hline 15 & 4296.67 & 1212.5 & 0.009 \\
\hline 16 & 3690 & 1212.5 & 0.011 \\
\hline 17 & 4281.67 & 1212.5 & 0.009 \\
\hline 18 & 3581.67 & 1746 & 0.016 \\
\hline 19 & 3426.67 & 2376.5 & 0.023 \\
\hline 20 & 3375 & 2376.5 & 0.023 \\
\hline 21 & 2833.33 & 2376.5 & 0.028 \\
\hline 22 & 3135 & 1746 & 0.019 \\
\hline 23 & 2405 & 1212.5 & 0.017 \\
\hline 24 & 3000 & 1212.5 & 0.013 \\
\hline 25 & 3655 & 1212.5 & 0.011 \\
\hline 26 & 3855 & 1746 & 0.015 \\
\hline 27 & 4031.67 & 2376.5 & 0.020 \\
\hline 28 & 3248.33 & 1212.5 & 0.012 \\
\hline 29 & 4063.33 & 1212.5 & 0.010 \\
\hline 30 & 3591.67 & 1212.5 & 0.011 \\
\hline Average & 3470 & 1449 & 0.014 \\
\hline
\end{tabular}


During academic year 2009-2013, the rate of generated residual food waste in MFU is increased continuously, as seen in Table I. Food waste in MFU was collected during August -December 2014. It could calculate the rate of food waste generation is 0.014 kilogram/person/day. This rate was used for predict the generated food waste during academic year 2009 - 2019, as shown in Fig. 1.

In the part of chemical properties, it was found that the moisture content of this waste is around $72.11 \%$ and total solid is around 27.89. The solid contented $93.91 \%$ of fixed carbon and $6.09 \%$ of ash. These results are used for forecast the energy and GHG emission from food waste.

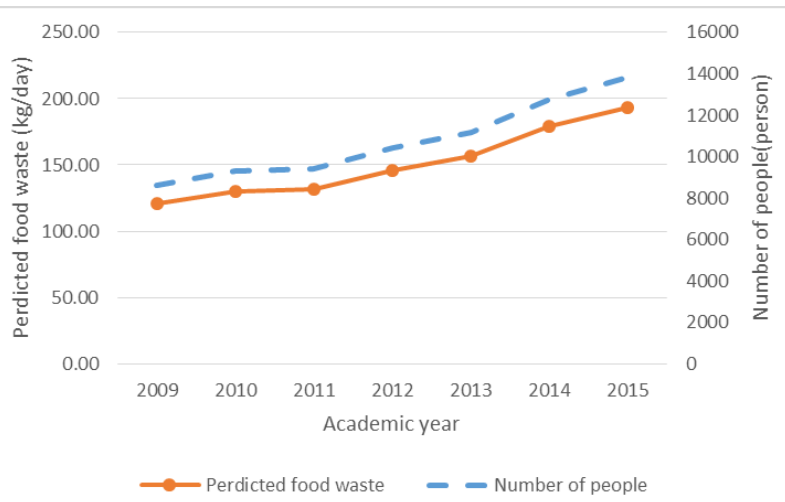

Fig. 2. Predicted amount of food waste during academic year 2009-2015.

\section{B. The Greenhouse Gas Emissions from Food Waste}

From the Table II represent emission GHG between academic year 2009-2015. It could be seen that the food waste is around $603.72 \mathrm{~kg} /$ day that was resulted in $\mathrm{CO}_{2}$ emission $1527.40 \quad \mathrm{KgCO}_{2} \mathrm{e} / \mathrm{kg}, \mathrm{CH} 4$ emission 12678.015 $\mathrm{KgCO}_{2}$-eq/day. These were also increasing every year.

TABLE II GHG FROM FOOD WASTE AT MFU DURING ACADEMIC YEAR

\begin{tabular}{cccc}
\hline $\begin{array}{c}\text { Academic } \\
\text { year }\end{array}$ & $\begin{array}{c}\text { Number of } \\
\text { people }\end{array}$ & $\begin{array}{c}\text { Predicted food } \\
\text { waste }(\mathbf{k g} / \text { day })\end{array}$ & $\begin{array}{c}\text { GHG } \\
\text { (ton } \\
\text { CO } \\
\text { /day) }\end{array}$ \\
\hline $\mathbf{2 0 0 9}$ & 8625 & 120.75 & 0.31 \\
\hline $\mathbf{2 0 1 0}$ & 9282 & 129.95 & 0.33 \\
\hline $\mathbf{2 0 1 1}$ & 9395 & 131.53 & 0.33 \\
\hline $\mathbf{2 0 1 2}$ & 10427 & 145.98 & 0.37 \\
\hline $\mathbf{2 0 1 3}$ & 11179 & 156.51 & 0.40 \\
\hline $\mathbf{2 0 1 4}$ & 12791 & 179.07 & 0.45 \\
\hline $\mathbf{2 0 1 5}$ & 13813 & 193.38 & 0.49 \\
\hline Note: $\mathrm{CO}_{2}$ factor $($ Kg CO2eq /unit) of food waste $=2.53[13]$
\end{tabular}

\section{Production from Food Waste via COWTEC®}

As the specification of $\mathrm{COWTEC}^{\circledR}[10]$, the generated biogas and compost from food waste at MFU could be calculated in Table III. Biogas is directly using as cooking fuel in canteen and compost could be sell.

TABLE III: THE GENERATED BIOGAS AND COMPOST FROM FOOD WASTE AT MFU BY USING COWTEC®

\begin{tabular}{|c|c|c|c|c|}
\hline Academic year & $\begin{array}{c}\text { Predicted food waste } \\
(\mathrm{kg} / \text { day })\end{array}$ & Biogas generation $\left(\mathrm{m}^{3} /\right.$ day $)$ & $\begin{array}{c}\text { Electrical equivalent } \\
(\mathrm{kWh} / \text { day })\end{array}$ & $\begin{array}{l}\text { Compost with } 35 \% \\
\text { moisture (kg/day) }\end{array}$ \\
\hline 2009 & 120.75 & 12.08 & 14.49 & 18.11 \\
\hline 2010 & 129.95 & 12.99 & 15.59 & 19.49 \\
\hline 2011 & 131.53 & 13.15 & 15.78 & 19.73 \\
\hline 2012 & 145.98 & 14.60 & 17.52 & 21.90 \\
\hline 2014 & 179.07 & 17.91 & 21.49 & 26.86 \\
\hline 2015 & 193.38 & 19.34 & 23.21 & 29.01 \\
\hline
\end{tabular}

TABLE IV: SUMMARY OF COST FOR BIOGAS PRODUCTION FROM COWTEC $®$

\begin{tabular}{|c|c|c|c|c|c|c|c|}
\hline \multirow[b]{2}{*}{ Parameter } & \multicolumn{7}{|c|}{ Year } \\
\hline & 2009 & 2010 & 2011 & 2012 & 2013 & 2014 & 2015 \\
\hline $\begin{array}{l}\text { Predicted food waste } \\
\text { (ton/year) }\end{array}$ & 28.98 & 31.19 & 31.57 & 35.03 & 37.56 & 42.98 & 46.41 \\
\hline $\mathrm{CO}_{2} \mathrm{e}$ (ton/year) & 73.32 & 78.9 & 79.87 & 88.64 & 95.03 & 108.73 & 117.42 \\
\hline $\begin{array}{c}\text { Biogas generation } \\
\left(\times 10^{3} \mathrm{~m}^{3} / \text { year }\right)\end{array}$ & 2.90 & 3.12 & 3.16 & 3.50 & 3.76 & 4.30 & 4.64 \\
\hline $\begin{array}{l}\text { Cooking gas equivalent } \\
\text { (ton/year) }\end{array}$ & 1.33 & 1.43 & 1.45 & 1.61 & 1.73 & 1.98 & 2.13 \\
\hline Compost (ton/year) & 4.35 & 4.68 & 4.74 & 5.26 & 5.63 & 6.45 & 6.96 \\
\hline $\begin{array}{l}\text { Saving cost for cooking gas* } \\
\left(\mathrm{x} 10^{3} \mathrm{baht} / \mathrm{year}\right)\end{array}$ & 27.31 & 29.40 & 29.75 & 33.02 & 35.40 & 40.51 & 43.74 \\
\hline $\begin{array}{l}\text { Saving cost for compost } * \\
\left(\mathrm{x} 10^{3} \mathrm{baht} / \text { year }\right)\end{array}$ & 26.08 & 28.07 & 28.41 & 31.53 & 33.81 & 38.68 & 41.77 \\
\hline $\begin{array}{c}\text { Cost of } \mathrm{CO}_{2} \mathrm{e} \text { avoidance } \\
\left(\mathrm{x} 10^{3} \mathrm{baht} / \mathrm{year}\right)^{*}\end{array}$ & 42.61 & 45.86 & 46.42 & 51.52 & 55.23 & 63.19 & 68.24 \\
\hline $\begin{array}{l}\text { Net annual cash inflow } \\
\left(\times 10^{3} \text { baht/year }\right)^{* *}\end{array}$ & 57.01 & 64.32 & 65.58 & 77.07 & 85.44 & 103.38 & 114.76 \\
\hline
\end{tabular}

*Note :Cooking gas price is $20.49 \mathrm{bath} / \mathrm{kg}$ [14] , compost price $6 \mathrm{baht} / \mathrm{kg}[15]$ and $\mathrm{CO}_{2}$ avoidance $581.20 \mathrm{bath} / \mathrm{tonCO}_{2} \mathrm{e}$ [16]. As seen from calculation, the conversation of food waste to energy via this machine is favored for investment when added the benefit of environment 


\section{Economies Analysis}

Actually, the study period of MFU is 2 semesters or 240 days/year. Therefore, this analysis was based on the duration. The productivity of food waste and economic analysis are summarized in Table 4. As the amount of predicted food waste, it could invest for $\operatorname{COWTEC}^{\circledR}$ with capacity 100 $\mathrm{kg} /$ day.

Average Net annual cash inflow is $81,081.13$ baht, so

$$
\operatorname{Payback}(\text { year })=\frac{390,000}{81,081.13}=4.81 \text {. }
$$

\section{CONCLUSION}

The results shown that the amount of food waste is directly variated with the number of student in MFU. However, the food waste could be converted to biogas and compost instead of sent to landfill by using COWTEC $^{\circledR}$ which is advantaged for GHG reduction. From the prediction, the GHG will be reduced around 117.42 ton $\mathrm{CO}_{2}$ e per year in 2015 which is resulted in saving the money for $\mathrm{CO} 2 \mathrm{e}$ avoidance about 68,240 baths per year. This investment of COWTEC $®$ technology will be advantaged when include the cost of $\mathrm{CO}_{2} \mathrm{e}$ avoidance with the payback period 4.81 years.

\section{REFERENCES}

[1] C. Nellemann, "The environmental food crisis: The environment's role in averting future food crises : A UNEP Rapid response assessment," UNEP/Earthprint, 2009.

[2] J. K. Andersen, A. Boldrin, T. H. Christensen, and C.Scheutz. (December 2010). Greenhouse gas emissions from home composting of organic household waste. Waste Management. [Online]. 30(12). pp. 2475-2482. Available: https://www.sciencedirect.com/science/article/pii/S0956053X100034 42

[3] M.-H. Kim and J.-W. Kim. (September 2010). Comparison through a LCA evaluation analysis of food waste disposal options from the perspective of global warming and resource recovery. Sci. Total Environ. [Online]. 408(19). pp. 3998-4006. Available: https://www.sciencedirect.com/science/article/pii/S004896971000445 6

[4] F. Girotto, L. Alibardi, and R. Cossu. (November 2015). Food waste generation and industrial uses: A review. Waste Manage. [Online]. 45(1). pp. 32-41. Available: https://www.sciencedirect.com/science/article/pii/S0956053X150042 01

[5] T. P. T. Pham, R. Kaushik, G. K. Parshetti, R. Mahmood, R. Balasubramanian. (April 2015). Food waste-to-energy conversion technologies: Current status and future directions. Waste Manage. [Online]. 38(0). pp. 399-408. Available: https://www.sciencedirect.com/science/article/pii/S0956053X140058 19

[6] T. Kaosol. (Mar. 2010). Sustainable solutions for municipal solid waste management in Thailand. J. Civil Eng. and Arch. [online]. 4(3). pp. $57-65$ Available: http://www.davidpublisher.org/index.php/Home/Article/index?id=340 36.html

[7] A. Ussawarujikulchai, P. Hansuk, P. Peerakiatkhajohn, "Zero waste mangement in Mahidol University Salaya Campus," J. Environ. Manag., vol. 7, no. 1, p. 12, 2011.

[8] Y. L. Chiew, J. Spångberg, A. Baky, P.-A. Hansson, and H. Jönsson. (February 2015). Environmental impact of recycling digested food waste as a fertilizer in agriculture - A case study. Res., Conser. and Recyc. [Online]. 95(0). pp. 1-14. Available: https://www.sciencedirect.com/science/article/pii/S092134491400261 4

[9] C. Mao, Y. Feng, X. Wang, G. Ren. ( May 2015). Review on research achievements of biogas from anaerobic digestion. Renew. Sust. Energ. Rev. [Online]. 45(0). pp. 540-555. Available: https://www.sciencedirect.com/science/article/pii/S136403211500120 3

[10] L. Microbiotec, Benifits of Cowtec, 2017.

[11] M. Franchetti. (July 2013). Economic and environmental analysis of four different configurations of anaerobic digestion for food waste to energy conversion using LCA for: A food service provider case study. J. Environ. Manage. [Online]. 123. pp. 42-48. Available: https://www.sciencedirect.com/science/article/pii/S030147971300155 2

[12] T. H. Kwan et al., "Techno-economic analysis of a food waste valorization process via microalgae cultivation and co-production of plasticizer, lactic acid and animal feed from algal biomass and food waste," Bioresour. Technol., vol. 198. pp. 292-299, December 2015.

[13] Carbon Label Project, Emission Factor 2016, Carbon Larbon label\& Carboon footprint for organization.

[14] Cooking gas price. (2017). [Online]. Available: http://law.dit.go.th/SearchResultSub_2UI.aspx?DocID=4501\&DocPar entID $=4517$

[15] Organic fertilizer prodcution process. (2017). [Online]. Available: http://sisaengtham.net/news/2017/step-do-compost-organic-fertilizer

[16] T. Vahlenkamp, Costs and Potentials of Greenhouse Gas Abatement in Germany 2007, McKinsey\&Company, Inc., p. 66.

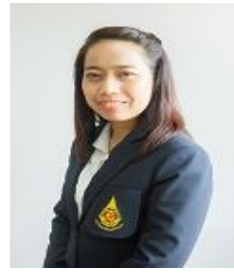

and environment.

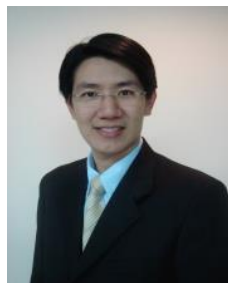

P. Dokmiagnam was born in Samut Songkran, Thailand in 1981. She graduated from the Joint Graduat School of Energy and Environment, KMUTT, Thailand in 2010 with a Ph.D of energy technology.

She is currently working as a lecturer in Mea Fah Luang University, Thailand. Her research particularly focused on the area of renewable energy

N. Laosiripojana was born in Thailand. He graduated from Imperial College London (UK) in 2003 with a Ph.D. of chemical engineering

$\mathrm{He}$ is a full time professor in the Joint Graduate School of Energy and Environment, KMUTT (Thailand). His research focused catalytic processes for alternative and renewable fuel productions as well as biorefinery application. 